\title{
Disseminated Molluscum Contagiosum in a Patient on Fingolimod for Multiple Sclerosis
}

\author{
Mounia Bennani*, Selma Benkirane, Jihane Ziani, Sara Elloudi, Hanane Baybay, Zakia Douhi \\ and Fatima Zahra Mernissi \\ Departement of dermatologie, Hassan II hospital Univesity of Fes, Morocco \\ *Corresponding author: Mounia Bennani, Departement of dermatologie, Hassan II hospital Univesity of Fes, Morocco
}

\begin{tabular}{|c|c|}
\hline ARTICLE INFO & ABSTRACT \\
\hline Received: March 14, 2020 & Citation: Mounia Bennani*, Selma Benkirane, Jihane Ziani, Sara Elloudi, Hanane Baybay, \\
\hline Published: 幽 April 02, 2020 & $\begin{array}{l}\text { et al., Disseminated Molluscum Contagiosum in a Patient on Fingolimod for Multiple } \\
\text { Sclerosis. Biomed J Sci \& Tech Res 26(5)-2020. BJSTR. MS.ID.004418. }\end{array}$ \\
\hline
\end{tabular}

\section{Editorial}

A 29-year-old man followed in neurology for multiple sclerosis for 5 years, put under several treatments without improvement, with installation of a paraplegia where the change of the treatment, and the patient was then put on fingolimod at the dose of $0.5 \mathrm{mg} /$ $\mathrm{mg}, 2$ months after the start of treatment, the patient has developed multiple asymptomatic papules, located everywhere on the body, such at the trunk, ,neck, back, 4 limbs and at the genital area, the patient has then consulted in dermatology 5 months after the appearance of these skin lesions. Physical examination revealed multiple waxy lesions, which were skin-colored domeshaped

papules with diameters of 2 to $10 \mathrm{~mm}$ some of which showed central umblication (Figures 1-3). Serologic tests for HIV-1, hepatitis C and B , and Syphilis tests returned negative. CD4+ T-cells count was obtained and was significantly low -350 cells $/ \mathrm{mm}$. Skin biopsy confirmed the clinical diagnosis of molluscum contagiosum. Due to the patient's economic status, the majority of lesions were individually removed mechanically However, it was necessary to repeat the procedure several times to remove all lesions. In addition, the patient was also put on potassium hydroxide solution $5 \%$ for local application, with regression of all lesions after 3 months of treatment.

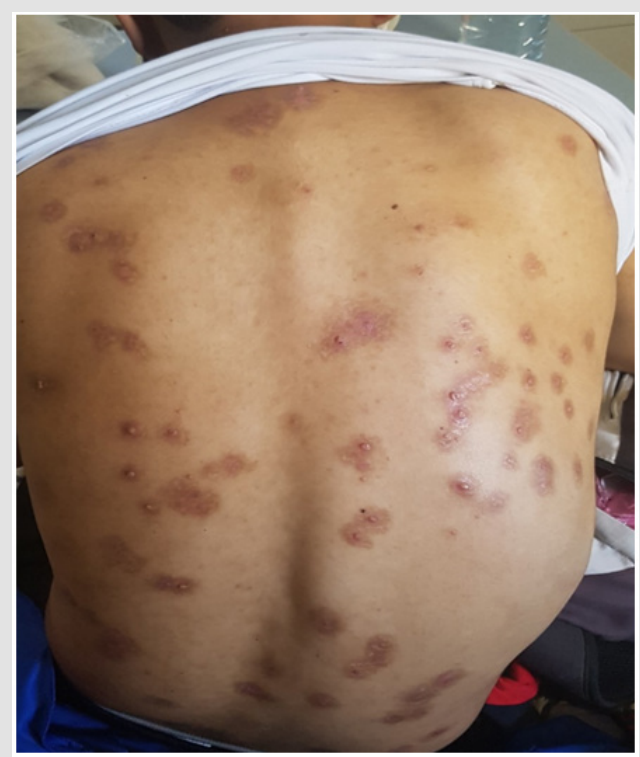

Figure 1: Multiple molluscum contagiosum in the back. 


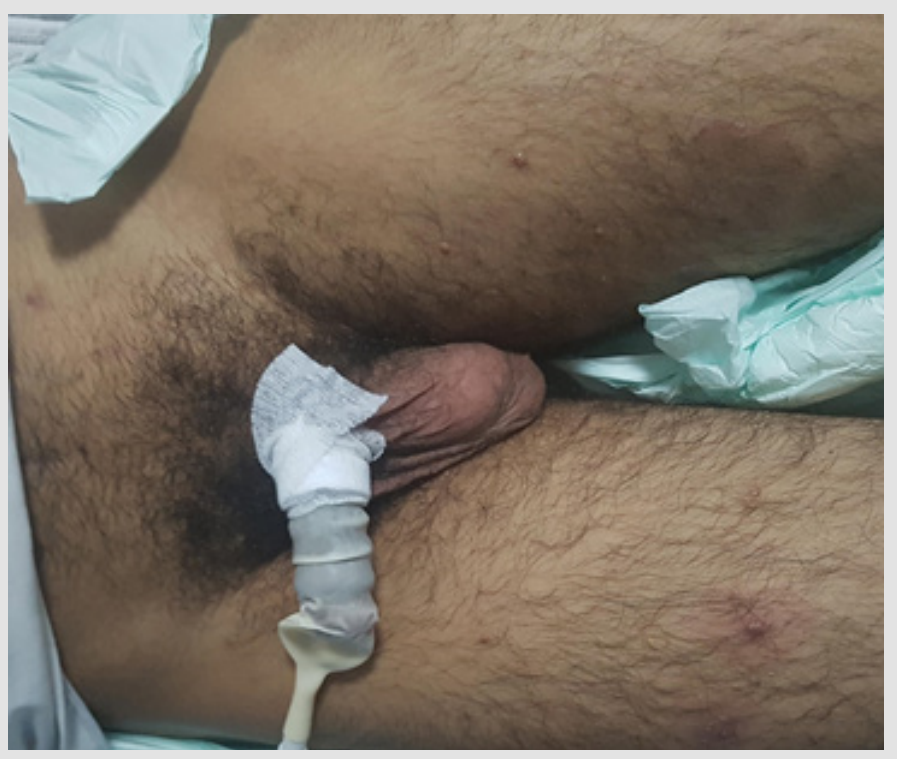

Figure 2: Molluscum contagiosum on the thighs.
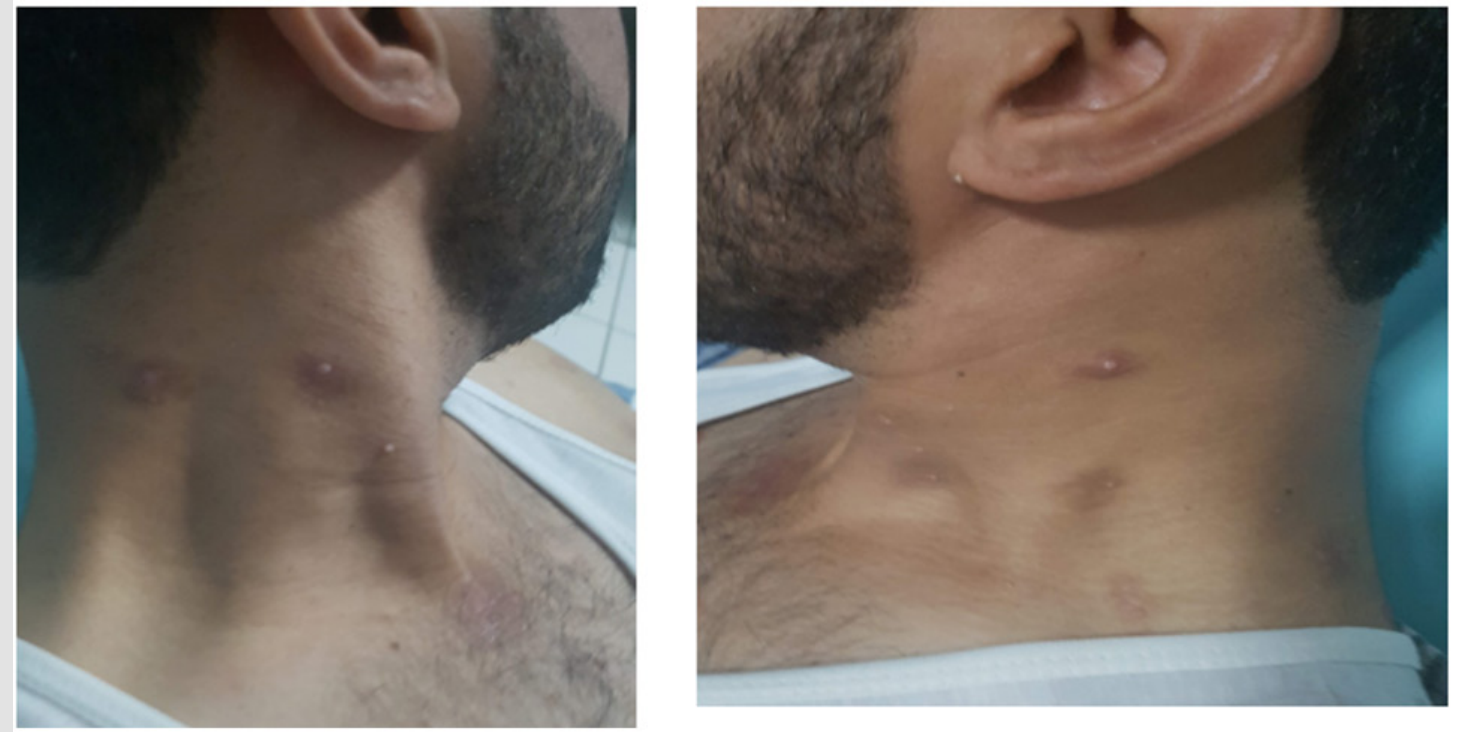

Figure 3: Multiple molluscum contagiosum at the neck.

Molluscum contagiosum is commonly a self-limiting condition occurring in children [1] it is a benign viral skin disease caused by the molluscum contagiosum virus of the Poxviridae family, which is transmitted by direct contact [2]. In the case of typical lesions the diagnosis is straightforward [3], widespread infection can be encountered occasionally in patients with impaired cell-mediated immunity [1] its frequently occurs as an opportunistic infection in immunocompromised patients, and there seems to be a correlation between the extent and severity of molluscum contagiosum and lower CD4-positive T-lymphocyte counts [4]. This has been shown by some previous reports of widespread molluscum contagiosum infection in patients treated with immunosuppressive drugs [2] such as topical calcipotriol / betamethasone (C / B) in an immunocompetent adult [5] in this patient this was explained by the fact that the patient continued the application of C / B ointment on normal skin long after the complete resolution of his skin prsoriasis thus inducing a shift of the immune response in the Th2 direction, as in AD patients. Also in patients on systemic therapy such as methrotrexate [1,2] after alemtuzumab in a patient with chronic lymphocytic leukaemia [4] Ruxolitinib which is a Janus kinase 1 and 2 inhibitor in a patient with polycythemia vera [6] and in patients receiving tumor necrosis factor alpha inhibitors [7]. It has also been reported in HIV-positive patients with Severe immune suppression, and CD4 + T-cells $<100$ cells / mm3 [3].

In the mid-1980s, atypical molluscum contagiosum was recognized as a feature of HIV infection but with widespread use of HAART, lesions are now less frequently observed in Western countries [8]. But high burden of lesions such as our patient 
had is uncommon. Our patient was on fingolimod which is a new pharmacological agent used as a background treatment for multiple sclerosis (MS), an autoimmune demyelinating disease of the central nervous system, with lymphopenic properties and this by reversibly sequestering lymphocytes at the level of secondary lymphoid organs by inhibiting their exit by an antagonistic action on the sphingosine1-phosphate receptors, and would thus prevent the passage in the central nervous system of the lymphocytes involved in the autoimmune response, This results in an overall decrease the number of circulating lymphocytes [9]. This explains this significant desiccation of lesions in our patient who has a low blood lymphocyte level. Treatment options for disseminated molluscum contagiosum developing with immunosuppressive therapy include discontinuing the immunosuppressive therapy followed by manual extraction, chemical cauterization, or cryotherapy [1]. Here, we report the first case of Disseminated MC caused by fingolimod. Notably, the severity of MC was much higher than that of conventional MC.

\section{References}

1. Relhan V, Roy E, Garg V, Khurana N, Bansal S (2014) Disseminated molluscum contagiosum in a patient on methotrexate therapy for psoriasis. Indian Journal of Dermatology, Venereology, and Leprology [Internet]. Medknow 80(2): 179-180.

2. Lim KS, CCI Foo (2007) Disseminated Molluscum Contagiosum in a Patient with Chronic Plaque Psoriasis Taking Methotrexate. Clinical and Experimental Dermatology 32(5): 591-593.

ISSN: 2574-1241

DOI: $10.26717 /$ BJSTR.2020.26.004418

Mounia Bennani. Biomed J Sci \& Tech Res

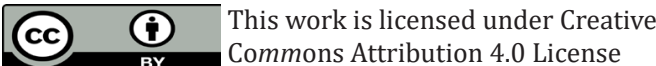

Submission Link: https://biomedres.us/submit-manuscript.php
3. Filo Rogulska M, Pindycka Piaszczyńska M, Januszewski K, Jarząb J (2013) Disseminated atypical molluscum contagiosum as a presenting symptom of HIV infection. Advances in Dermatology and Allergology [Internet]. Termedia Sp zoo 30(1): 56-58.

4. Pitini V, Arrigo C, Barresi G (2003) Disseminated molluscum contagiosum in a patient with chronic lymphocytic leukaemia after alemtuzumab. British Journal of Haematology [Internet]. Wiley 123(4): 565-565.

5. Bae JY, Lee JI, Jang DH, Jung HJ, Park MY, et al. (2020) A case of disseminated molluscum contagiosum caused by topical calcipotriol/ betamethasone in an immunocompetent adult. JDDG: Journal der Deutschen Dermatologischen Gesellschaft [Internet]. Wiley 18(1): 4446.

6. Kinoshita M, Ogawa Y, Kawamura T, Kirito K, Shimada S (2016) Case of disseminated molluscum contagiosum caused by ruxolitinib, a Janus kinase 1 and 2 inhibitor. The Journal of Dermatology [Internet]. Wiley 43(11): 1387-1388.

7. Gur I (2008) The epidemiology of Molluscum contagiosum in HIVseropositive patients: a unique entity or insignificant finding? Int J STD AIDS 19(8): 503-506.

8. Azevedo T, Catarino A, Ferreira L, Borges F, Mansinho K (2017) Disseminated molluscum contagiosum lesions in an HIV patient. Cleveland Clinic Journal of Medicine [Internet]. Cleveland Clinic Journal of Medicine 84(3): 186-187.

9. A Chardain, B Stankoff (2012) Mécanisme d'action et applications thérapeutiques du fingolimod Mechanism of action and therapeutic applications of fingolimod La Lettre du Pharmacologue 26(3).

$\begin{array}{ll}\text { BIOMEDICAL } & \text { Assets of Publishing with us } \\ \text { RESEARCHES } & \text { - Global archiving of articles } \\ & \text { - Immediate, unrestricted online access } \\ \end{array}$

